\title{
DADOS DIRIGINDO A VIDA FORA DE SEQUÊNCIA: DERIVAS ENTRE ESTUDOS DA CIÊNCIA E DA TECNOLOGIA E PESQUISA EM EDUCAÇÃO
}

\author{
JOHN A. WEAVER ${ }^{1}$ \\ ORCID: https://orcid.org/0000-0002-8989-5941 \\ THIAGO RANNIERY ${ }^{2}$ \\ ORCID: https://orcid.org/0000-0003-4399-2663
}

\begin{abstract}
RESUMO: Este artigo explora derivas entre os estudos da ciência e da tecnologia e a pesquisa em educação, e é pautado pela obra de Steven (2013), na qual o autor traça um passeio etnográfico e histórico sobre laboratórios de bioinformática. O artigo foi concebido a partir de uma conversa entre autores que, oriundos de distintos países, foram instados a comentar ilações epistemológicas e ontológicas das transformações tecnológicas das ciências da vida para a pesquisa em educação. $\mathrm{Na}$ materialidade da escrita, o ensaio percorre lacunas do processo de sequenciamento genético e da produção tecnologicamente mediada de dados como disparadores para preparar pedagogicamente a nós mesmos e aos outros para uma vida que já estamos vivendo. $O$ argumento é de que cabe à pesquisa em educação explorar práticas científicas de uma forma imaginativamente mobilizadora para que se possam mudar as questões que fazemos sobre vida, conhecimento e política em um ambiente mais que "humano".
\end{abstract}

Palavras-chave: dados, ciência e tecnologia, bioinformática.

\section{DATA DRIVING LIFE OUT OF SEQUENCE: INTERFACES BETWEEN STUDIES OF SCIENCE AND TECHNOLOGY AND EDUCATION RESEARCH}

\begin{abstract}
This article explores connections between science and tecnology studies and research in the field of education, and is based on the work of Stevens (2013), who takes us on an ethnographic and historical stroll among bioinformatics laboratories. The article was conceived during a conversation between the co-authors, who come from different countries and were urged to make and comment on epistemological and ontological inferences from the transformational technologies in the life sciences for education research. The essay looks at gaps in genetic sequencing processing and in the technologically mediated production of data in order to pedagogically prepare ourselves and others for a life that we are already living. Our argument is that it is up to research in the field of education to explore scientific practices in a way that imaginatively mobilizes people, so that we can change that questions we make about life, knowledge and politics in a more than "human" environment.
\end{abstract}

Keywords: data, science and technology, bioinformatics.

\footnotetext{
${ }^{1}$ Georgia Southern University (GSU). Statesboro, GA, Estados Unidos. <jweaver@georgiasouthern.edu>

${ }^{2}$ Universidade Federal do Rio de Janeiro (UFRJ). Rio de Janeiro, RJ, Brasil. <t.ranniery@gmail.com> Educação em Revista|Belo Horizonte|v.36|e221497|2020
} 


\title{
DATOS CONDUCIENDO LA VIDA FUERA DE SECUENCIA: DERIVAS ENTRE ESTUDIOS DE LA CIENCIA Y DE LA TECNOLOGÍA E INVESTIGACIÓN EN ENSEÑANZA
}

\begin{abstract}
RESÚMEN: Este artículo explora derivas entre los estudios de ciencia y de la tecnologia y la investigación en enseñanza, y es movido por la pieza de Steven (2013), en la cual el autor diseña una vuelta etnográfica e histórica acerca de los laboratorios de bioinformática. El artículo fue concebido a partir de una charla entre autores que, procedentes de diferentes países, fueron instados a comentar conclusiones epistemológicas y ontológicas de las modificaciones tecnológicas de las ciencias de la vida para la investigación en enseñanza. En la materialidad de la escritura, el ensayo percorre huecos del proceso de secuenciamiento genético y de la producción tecnologicamente mediada de datos como disparadores para preparar pedagógicamente a nosotros mismos y a los otros para una vida que ya estamos viviendo. El argumento es de que corresponde a la investigación en enseñanza explorar prácticas científicas de manera imaginariamente movilizadora para que se puedan cambiar las cuestiones que hacemos sobre vida, conocimiento y política en un ambiente más que "humano".
\end{abstract}

Palabras clave: datos, ciencia y tecnología, bioinformática.

\section{INTRODUÇÃO}

Existe um best-seller, em língua inglesa, intitulado Purpose Driven Life, de autoria do pastor Rick Warren (2002). Explícito em seu título está o verbo dirigir, que pressupõe a conhecida figura do indivíduo, a imagem manifesta do "humano" cristão ocidental que cria o significado e, com a mão de Deus - para sempre, onipotente e onisciente -, determina o curso de ação a ser tomado. Essa é uma visão de mundo tipicamente moderna: um indivíduo "humano" que controla seu próprio destino e, uma vez que o tenha alcançado, onde quer que esse destino se situe, vê-se obrigado a reconhecer que essa era a vontade de Deus o tempo todo. Essa história corriqueira de autonomia individual e causalidade mística está sendo vastamente corroída. O título deste artigo e sua alusão ao livro recente de Hallem Steven (2013), Life out of Sequence - algo como A vida fora de sequência -, apontam para a constatação de que quaisquer suposições modernas sobre a vida demandam uma transformação radical. Assim, de um lado, quer se queira ou não, os indivíduos não são mais os condutores autônomos de suas próprias existências - talvez jamais o tenham sido - ou de qualquer aspecto da realidade. Os indivíduos, para radicalizar a metáfora, estão no veículo, mas em um veículo sem motorista. São passageiros com algum controle, porém um controle totalmente incompleto. De outro lado, seria preciso observar no que a vida está se tornando, na realidade, ao ser fabricada "nas práticas tecnocientíficas mudando o mundo por meio de determinados atores coletivos em tempos e lugares particulares" (HARAWAY, 1993, p. 297). Este é um processo que nunca pode ser recriado de maneira tão autonomista. A recriação da vida opera fora de sequência, assim como tiraremos a obra de Steven da sua sequência para criar algo a partir dela.

Neste artigo, partimos de uma discussão sobre a etnografia realizada por Steven em laboratórios de bioinformática. Ao seguir a tradição aberta por Bruno Latour e Steve Woolgar (1979) e Andrew Pickering (1995), Stevens demonstra, em seu trabalho, como a vida está sendo redefinida pelo data em todos os seus níveis fundamentais, nos cruzamentos entre biologia e capitalismo. A expressão inglesa para designar o plural de dados contém alguma ambiguidade desde que passou a ser usada para se referir a um grande volume de dados produzidos e acumulados tecnologicamente. Vamos sugerir que um modo de entender as implicações da bioinformática para a pesquisa em educação não está em olhar a vida a partir de categorias ontológica e epistemologicamente separadas. A vida é simultaneamente uma experiência ontoepistêmica. Nas páginas que se seguem, vamos explorar as lacunas abertas no processo de sequenciamento tecnológico do DNA realizado em laboratórios de bioinformática, mapeados por Steven, em algo próximo ao esquema motor mobilizado por Catherine Malabou (2005), no qual certas ideias-força ganham potencialidade teórica. São essas lacunas que fornecerão, em nosso argumento, o espaço ético-político para reivindicarmos algum sentido da vida. É nessas lacunas que nós, como 
pesquisadores em educação, encontraremos também nuances para preparar pedagogicamente a nós mesmos e aos outros para uma vida que já estamos vivendo e viveremos mais intensamente em um futuro próximo. Em torno desses nossos movimentos, estão a bioinformática e os dados criados por entidades "não-humanas". É, pois, com esse pano de fundo, que exploraremos derivas entre os estudos da ciência e da tecnologia e a pesquisa em educação ${ }^{3}$.

É relevante explicitar, de partida, que este ensaio foi construído por pesquisadores implicados no campo do currículo que estão interessados em explorar os efeitos éticos, políticos e, sobretudo, imaginativos, dos estudos da ciência e da tecnologia. Há, nessas paragens, nesses "nodos ou nós, material-semióticos em que corpos e significados diversos se co-formam um ao outro" (HARAWAY, 2008, p. 18), algo acontecendo com as modernas categorias do discurso pedagógico ${ }^{4}$, tais como "humano" e "natureza" ou mesmo "política", que valeria a pena explorar e revisitar. Se "a tarefa de uma teoria curricular comprometida com a alteridade [...] é pôr em questão os seus próprios fundamentos" (Macedo, 2017a, p. 551), recorremos a uma sugestão instrutiva de Stelio Marras (2018, p. 261) sobre como "é da produção científica que podemos recolher medidas que apontam para o descentramento do humano moderno no cosmos". Embora esse recurso não seja um desconhecido da pesquisa em currículo no Brasil desde, pelo menos, a tradução do Manifesto Ciborgue de Donna Haraway (2009), em coletânea organizada por Tomaz Tadeu, ou da introdução assinada por Alfredo Veiga-Neto e Maria Lúcia Wortmann (2001), pouco acompanhamos as correntes teóricas ${ }^{5}$, muitas vezes díspares, que, ao invés de demitirem as práticas das ciências do exercício de pensamento, encontraram nos contornos da materialidade científica contemporânea um mote para reconfigurações da natureza da substância viva. $\mathrm{Na}$ verdade, que as ciências viriam a se tornar territórios de especulação imaginativa filosófica, foi algo que Bachelard (2001) apontou ainda no início do século XX'

A referência ao livro Life of out sequence de Steven ao longo do texto não é, de todo, por acaso. Este artigo materializa um debate originalmente realizado entre pesquisadores de distintas nacionalidades (um brasileiro e um americano). Nossa conversação buscava responder ao convite de, a partir de comentários em torno de uma das etnografias mais relevantes daquilo que as ciências da vida vieram a se tornar nas últimas décadas, discutir ilações epistemológicas e ontológicas para a pesquisa educacional. O exercício de, agora, transformar uma forma de conversa em inglês em um texto em português busca apresentar ao contexto brasileiro questões derivadas dos estudos da ciência e tecnologia para a pesquisa em educação, sua imaginação, sua poética e sua política. Onde tradições díspares de conhecimentos se aproximam e se enredam, há "esperança de transformar contextos de exercício do poder" (VERRAN, 2002, p, 730). Com efeito, nós esperamos que, entre as sessões a seguir, as transformações cartografadas por Steven funcionem para provocar momentos de teorizar, de outros modos, a pesquisa em educação. Como pano de fundo, há, de nossa parte, uma expectativa em indicar que o descentramento em curso do "humano" evoca o que Deborah Britzman (2009) chamou de espaço menos heróico do que as grandes narrativas de salvação do discurso pedagógico sobre as quais muito da política educacional se alicerça, mas nem por isso, ou talvez em virtude disso, nos desobriga de um vigoroso trabalho político - quiçá o intensifica.

\footnotetext{
${ }^{3}$ Escaparia aos propósitos deste artigo, além de extrapolar seus limites, uma ampla caracterização dos estudos da ciência e da tecnologia (science and technology studies). No entanto, a instrutiva síntese de Jensen (2017) indica que, sob a diversidade de abordagens, perspectivas e correntes, há um interesse comum pelas práticas materiais da ciência, pelos múltiplos enredamentos de entidades e coisas e por como algo chamado conhecimento é extraído desse emaranhado confuso.

${ }^{4}$ Esta é uma referência frouxa à formulação de Bernstein (1996). Reconhecemos, contudo, que talvez seja liberdade excessiva de nossa parte recorrer a um discurso pedagógico, posto que todo discurso é sempre múltiplo, heterogêneo e contingente. Trata-se, entretanto, de um uso sob rasura que reconhece como heranças articuladas de variadas tradições na pesquisa em educação estão implicadas na "própria pedagogia como operação constitutiva, isto é, [no] papel produtivo da pedagogia na fabricação ativa de indivíduos" (LARROSA, 2010, p. 37). A questão, como pretendemos demonstrar, é de que modo os estudos da ciência e da tecnologia permitem levar a sério, nesses jogos de transformação e subjetivação, descritos por Larrosa (2010), os aparatos e interfaces tecnológicos, os quais não são redutíveis à figura moderna do antropos.

${ }^{5}$ A referência envolveria movimentos que, sob o rótulo de virada ontológica, vêm afetando campos como a antropologia, a filosofia, os estudos feministas e queers e as humanidades de um modo geral, tais como realismo especulativo, neomaterialismo, neoempirismo e perspectivismo.

${ }^{6}$ A publicação original data de 1938.
} 
O mergulho em e através dos dados complica as políticas da metanarrativa de dominação tecnológica sobre a vida "humana" explorada, controlada e apagada. O que se torna pensável é uma política que surge do engajamento prático com o mundo dentro de uma ontologia diferente do conhecimento. Esse engajamento pode ser um disparador para produzir modalidades de pensamento que desafiam as suposições sobre o que é fazer pesquisa em laboratórios de biologia, seus objetos de investigação e seus praticantes - uma aventura conclamada por Natasha Myers (2015), por exemplo -, mas, sobretudo, nos conduz a realizar o indeterminado chamado do outro, que é, talvez, a insistência que mais tem nos importunado, como Spivak (1999) notou, desde a invasão da virada pós-moderna. Diante das descrições que tendem a aplainar as práticas dos cientistas, vamos insistir em transformá-las de forma que possam alterar o que pensamos sobre o que a ciência é e o que ela poderia se tornar, para que se possa abrir "uma ciência digna do mundo" (LATHER, 2016, p. 129). Nosso objetivo, ao utilizar um trabalho atual dos estudos de ciência e tecnologia sobre a produção biotecnologicamente mediada de dados é, pois, explorar percepções da prática científica de uma forma que se possam interrogar as questões que fazemos sobre a vida e sobre os modos de produção de conhecimento na pesquisa em educação. Escolhemos, deste modo, manter o flerte, quase no tom do que se poderia chamar de ensaioresenha, usando comentários da obra de Steven sobre a bioinformática que realizamos, naquela ocasião, como disparadores para insuflar a aliança que estamos defendendo.

Fazemos tal movimento, entretanto, não apenas tendo em vista a diminuta aproximação da pesquisa educacional com estudos da ciência e da tecnologia. Embora saibamos que o nosso subtítulo pode sugerir uma espécie de grande síntese ou resumo anunciativo do que os estudos da ciência e da tecnologia poderiam trazer, essa é uma escolha que nos permite evitar a abstração desse tipo de proposição aproximativa e insistir em derivas teóricas situadas e específicas. Os efeitos certamente seriam outros, caso fossem outros os interlocutores mobilizados. Nesse sentido, as ponderações que realizamos não podem ser vistas como decisivas, mas são necessariamente parciais. De forma alguma, este artigo pretende exaurir possibilidades. Ao invés disso, aponta para relações ontológicas e ético-políticas implicadas nas maneiras pelas quais o mundo é um ambiente "mais que humano". E, se vamos nos valer das aspas em demasia em torno dessas expressões "humano", "não-humano" e "mais que humano", suas declinações e derivados, é para, ao estilo sugerido por Butler (1998), colocar em suspensão a diferença substantiva entre "humanos" e seus outros ao mesmo tempo que nos valemos desses termos sem assentá-los ${ }^{7}$. Não sem algum risco de refundá-los, esperamos que este uso possa, por um lado, desmontar como essa diferença está situada em um nível estratégico do discurso modernista que esconde os trânsitos, composições e efeitos entre "humanos" e mundos, os quais não podem ser tomados como espelho da excepcionalidade da "humanidade" (LATOUR, 2013); e, por outro, destacar a associações de seres, ambientes e tecnologias muito heterogêneos entre si. Assim, não pretendemos descartar a categoria "humano", como se de resto fosse possível, mas tomá-la desde um nó emaranhado de relações propriamente "não-humanas", "mais que humanas" ou "inumanas" (HARAWAY, 2008; CHEAH, 2006).

Entretanto, antes de seguir nesta direção, não é demasiado marcar ainda que nós, como autores deste texto, respondemos a diferentes tradições teóricas da pesquisa em currículo em nossos países e dialogamos de forma espacial e temporalmente localizada com os estudos da ciência da tecnologia. Portanto, optamos por manter, em diversos momentos, as tensões implicadas na tarefa da tradução cultural que este tipo de escrita nos exigiu. Alguns dos termos propriamente laboratoriais da bioinformática também não foram traduzidos de forma proposital, tendo em vista que são usados por pesquisadores, inclusive brasileiros, em sua formulação em inglês. Eventualmente, esses são explicados em notas de rodapé ou ao longo do texto, sempre que nos pareceu necessário.

\footnotetext{
${ }^{7}$ As aspas com estes fins não foram usadas quando as mesmas expressões estão contidas em citações diretas. Educação em Revista|Belo Horizonte|v.36|e221497|2020
} 


\section{CRIANDO A VIDA FORA DE SEQUÊNCIA: UM PASSEIO POR UM MUNDO "MAIS QUE HUMANO"}

Imerso há vários anos no mundo da pesquisa em bioinformática, Stevens observou inúmeros laboratórios de sequenciamento genético e chegou a trabalhar em um deles durante seu percurso etnográfico. A partir dessas experiências, o autor nos apresenta um esboço íntimo de como o processo de sequenciamento ocorre - processo crucial para entender a redefinição da vida. $O$ trabalho começa com Molecular Biology Production Group, realizando vários testes para verificar a pureza e a qualidade de uma sequência genética. Logo depois, a sequência testada é cortada em "peças aleatórias de tamanho adequado para sequenciamento" (STEVENS, 2013, p. 110). Após cortadas, o próximo passo é descrito por Stevens (2013, p. 110) como um "processo de 5 a 6 dias de produção de uma biblioteca". Biblioteca é uma metáfora instigante para descrever a amplificação do material genético em "uma grande coleção de DNA curto (todo um cromossomo, por exemplo)" (STEVENS, 2013, p. 110). Em seguida, "as peças de DNA são tratadas quimicamente de forma que são incorporadas em outros pedaços de DNA, especialmente projetados, em forma de anel, chamados plasmídeos" (STEVENS, 2013, p.110). Stevens descreve como as placas de ágar são preparadas com uma solução desses plasmídeos transformados e como bactérias Escherichia coli, por aquecimento rápido ou choque elétrico, são induzidas a absorvê-los. O processo continua eliminando qualquer espécime de bactéria que não tenha se conectado com os plasmídeos, e somente aquelas amostras nas quais a E. coli se fundiu com eles crescerão em colônias.

O próximo grupo de trabalho, Core Sequencing, assumiu o protagonismo do sequenciamento. "Seu trabalho pode ser dividido em seis etapas. Primeiro, na etapa de 'picking', um grande robô projetado por uma empresa chamada Genetix usa uma câmera de alta resolução para escanear as placas de ágar a fim produzir imagens digitais" (STEVENS, 2013, p. 111). Neste ponto, o uso de metáforas, incluindo a descrição do processo como uma linha de montagem, como se fosse linear, demonstra como vários domínios da realidade são misturados na passagem do mundo microscópico ao macroscópico e do "humano" ao "mais do que humano". O uso da palavra picking é revelador. Metaforicamente, pode implicar, em inglês, tanto colheita quanto seleção. Nesse ponto, um de nós lembrou que, ao acompanhar uma experiência de transplante de órgãos, os órgãos transplantados eram, por exemplo, descritos como colhidos. O outro recordou como, em práticas de pesquisa em ciências biológicas que envolvem trabalho de campo, muito se fala sobre fazer coletas. Nesse cenário, a "colheita" é de algo menor que um órgão, mas a metáfora do enquadramento de Heiddeger ainda é um sinal de alerta quanto às implicações da bioinformática ${ }^{8}$. O aspecto "mais do que "humano" é igualmente importante nesse percurso. Todo o processo de coleta e construção de "bibliotecas" não seria possível sem os braços de robôs, as câmeras de alta resolução e as amostras digitalizadas. Se não houver tecnologia, não há picking nem biblioteca.

Nas palavras de Stevens, os passos seguintes são:

Essas imagens são processadas por softwares que identificam as colônias que são boas candidatas ao picking - isto é, colônias que mostram um bom crescimento e não estão muito próximas umas das outras [...] As amostras são colocadas novamente em um freezer. Segundo, a etapa TempliPhi gera amplificação adicional, usando um processo semelhante ao PCR para aumentar a quantidade de DNA [...]. Terceiro, [...], nucleotídeos especialmente projetados marcados com corantes fluorescentes são adicionados à amostra e incorporados às moléculas de DNA. [...] A quarta e quinta etapas são a 'precipitação por etanol' e 'eluição' [...] esses processos químicos são projetados para remover o excesso de corante e outros contaminantes. (STEVENS, 2013, p. 111-112).

Stevens faz, contudo, uma observação importante: esses cinco estágios estão longe de ser automatizados. Cada um deles envolve um cuidadoso trabalho de laboratório, testes e julgamentos. O aspecto minucioso e delicado é, entretanto, apagado quando etapas inteiras do processo de

\footnotetext{
8 Para Heidegger, a palavra enquadramento significa duas possibilidades diferentes. Pode significar encerrar ou fechar, mas também significa, como observa Samuel Weber (1996, p. 71), "uma força motriz da qual emerge um tipo diferente de topografia. Enquadrar, portanto, pode significar um desacoplamento que pode levar a novos acoplamentos". Isto é o que a bioinformática faz no processo descrito por Stevens. 
sequenciamento são descritas como pipeline. O processo de direção da vida é achatado, e as lacunas não serão apenas preenchidas. Em especial, tais lacunas são abertas para que a ideia de um "humano" se afirme como condutora dos dados. O passo final é a detecção. Aqui, "as amostras desaparecem totalmente através de plataformas virtuais. E é somente nessa etapa que as amostras são introduzidas nas máquinas de sequenciamento. [São] cerca de 120 detectores Applied Biosystems 3730 [...] operando vinte e quatro horas por dia, sete dias por semana" (STEVENS, 2013, p. 112). Mais importante, "as quatro possíveis bases de nucleotídeos são representadas por linhas de quatro cores diferentes em gráficos" (STEVENS, 2013, p. 112). Esses gráficos coloridos, conhecidos como traços de sequenciamento bruto, "são armazenados pelas máquinas de sequenciamento, mas ainda não estão 'finalizados" (STEVENS, 2013, p. 112). Nessas máquinas,

dois passos computacionais são executados automaticamente. O primeiro é conhecido como 'base calling' e geralmente é feito usando o software chamado Phred [que] converte um arquivo de imagem (o gráfico de quatro cores) em uma cadeia de texto [...] Ele também atribui uma pontuação de qualidade a cada base, refletindo sua confiança na 'calling' que realiza.

O software Phred serve como um árbitro das bases de nucleotídeos, nomeando-as ao ler as imagens e, mais ainda, qualitativamente determinando a precisão da leitura que ele mesmo produz. Não é isso que fazemos quando conduzimos pesquisas, interpretamos um texto, traduzimos um documento de uma língua para outra? O processo de sequenciamento, entretanto, ainda não está completo. Para gerar uma sequência passível de leitura, é preciso remontá-la. Um programa de computador chamado Phrap é usado para fazer isso. O Phrap usa os arquivos e o índice de qualidade gerado pelo Phred "para determinar a montagem mais provável, pesquisando segmentos sobrepostos” (STEVENS, 2013, p. 113). O processo de sequenciamento pode ser assim resumido: amostras coletadas são passadas para uma imagem digital; a imagem digital é, por sua vez, convertida em uma sequência a ser lida que, por fim, é produzida pelo software e está pronta para leitura em diferentes ordenações e cenários possíveis. Essa é a vida fora de sequência em seis passos (não tão) fáceis. A parte desconfortável vem quando algo de "humanidade" desse processo "mais do que humano" emerge. Apesar da sofisticação dos algoritmos e programas de computação, Stevens (2013, p. 113) observa que

eles geralmente não conseguem igualar todas as sequências $[\ldots]$ as lacunas permanecem. $\mathrm{O}$ trabalho da equipe de finalização é assumir o lugar onde a Phrap deixa as lacunas e consertá-las [...]. Seu trabalho é altamente especializado e requer conhecimento detalhado da biologia dos organismos que estão sendo sequenciados, das complexidades do processo de sequenciamento e do software [...] Quando existiam lacunas, a equipe de finalização importa uma sequência de dados de fontes que não haviam sido usadas na montagem (um banco de dados on-line, por exemplo) para começar a preenchê-las. Este trabalho é bastante meticuloso e depende crucialmente do julgamento da equipe de finalização (STEVENS, 2013, p. 113).

A partir da tendência de tomar os resultados apresentados pelos algoritmos que os programas executam, esquece-se que o desenvolvimento de "uma metodologia computacional está invariavelmente associada a uma inevitável quantidade de erros metodológicos" (PROSDOCIMI, 2006, p. 17). Na conclusão de Prodoscimi (2006, p. 17), esse "fato mostra quão sujos tendem a ser os dados biológicos sobre sequências de biomoléculas que obtemos dos mais afamados bancos de dados existentes para tanto". Onde perseguimos apenas que o processo de sequenciamento repousaria no aplainamento da vida, uma meta que inevitavelmente serve ao "funcionalismo brutal" (HANSEN, 2015, p. 58), a situação final soa mais para um pesadelo faústico. Porém, essas lacunas não são somente erros ou sinais daquilo que não pode ser representado; são constitutivas dessas novas configurações biotecnológicas dos laboratórios, "sempre em relação a um ecossistema bioinformatizado calculista" (DE FREITAS, 2016, p. 468). Embora a quantidade de imagens carregadas diariamente seja lida por algoritmos, as sequências legíveis são frequentemente preenchidas por profissionais, e esse entrelaçamento complica visões de um mundo automatizado e saturado de controle. Se a figuração dos dados destrona o "humano" tal como conhecemos, no mesmo movimento, convoca-o para além do limiar da própria percepção. É porque nenhum julgamento se dá fora desse espaço tecnologicamente transformado que as lacunas colocam uma 
relação infinitamente mais rica e profícua do que o imaginário atual do sequenciamento parece evocar. Ao invés de menosprezar o processo de sequenciamento como um simples tropo para imaginar o potencial (quase sempre, econômico) dos bancos de dados genéticos, as lacunas abrem uma oportunidade para imaginar as consequências materiais dos modos de viver, perceber e saber que atualmente formam esses mundos dos dados.

\section{DE LACUNAS E PIPELINES}

A palavra pipeline, que deixamos até agora sem tradução, é usada para descrever o processo de sequenciamento. Cada amostra utilizada durante o percurso recebe um código de barras quando entra na linha de produção, na pipeline - um jogo metafórico com a ideia de transportar algo através de um tubo. À medida que uma amostra se desloca pelo laboratório nos seis passos do sequenciamento, esse código de barras é repetidamente escaneado, e os resultados são armazenados em um sistema de gerenciamento de informações, o chamado LIMS. Tão logo "uma amostra é convertida em código e inserida no LIMS, ela se torna um objeto tanto real quanto virtual. O objeto real no laboratório não teria sentido sem que sua contraparte virtual o vinculasse ao pipeline" (STEVENS, 2013, p. 110 e 115). Podemos olhar para essa afirmação ao menos de dois modos. Primeiro, a amostra pode ser vista simultaneamente como um objeto ontológico e como um objeto de informação que pode se tornar conhecimento. A amostra é um objeto ontoepistêmico (RHEINBERGER, 1997; KNORR-CETINA, 1999), pois implica modos de pensar e fazer que constituem ativamente o mundo em que vivemos, e nos constituem como sujeitos e objetos do conhecimento (BARAD, 2007). Em segundo lugar, a amostra não tem sentido por si só, a menos que seja vista como uma criação implicada em propósitos "humanos", assim como uma criação "mais do que humana", inviável sem as bibliotecas digitais, os sistemas computacionais de gerenciamento de informações e objetos tecnológicos dos laboratórios.

Todo esse aglomerado compõe a pipeline. Nos laboratórios de bioinformática, somos apresentados a profissionais envolvidos em um mundo emaranhado com moléculas, modelos e máquinas. No entanto, a metáfora, sugere Stevens (2013, p. 115), "permite aos biólogos entender o sequenciamento como uma viagem pelo espaço, em vez de um processo ativo de extração e construção com tarefas manuais difíceis e convocações para julgamento ativo". Todavia, se assim o é, essa linha de produção tem seus limites. Como corolário, a produção metafórica está embutida em fenômenos materiais. Na afirmação de Karen Barad (2017), as "intra-ações" material-discursivas, isto é, a discursividade e a materialidade, não são reinos independentes que se referem um ao outro, ambos se moldam e se transformam mutuamente através de um "devir intra-ativo". Em suas palavras:

A relação entre o material e o discursivo é de implicação mútua. Nem as práticas discursivas nem os fenômenos materiais são ontologicamente ou epistemologicamente anteriores. Nenhum dos dois pode ser explicado em termos do outro, nem são redutíveis ao outro. Nenhum deles tem status privilegiado na determinação do outro. Nenhum, nem outro são articulados ou articuláveis na ausência do outro; matéria e significado estão mutuamente articulados (BARAD, 2007, p. 152).

Não somente o uso da metáfora pipiline autoriza que os profissionais envolvidos tomem o processo em termos lineares na medida em que o sequenciamento contém suas próprias lacunas. Sua linearidade é também uma prática material que funciona como um apagamento dos diferentes tipos de esgarçamentos que os membros das equipes de finalização estão buscando preencher. A metáfora funciona oferecendo a promessa de organizar e corrigir a bagunça até um ponto em que o fato de que os "humanos" não são mais os únicos seres que emitem julgamentos, que veem e que conhecem precisa ser (ou já está sendo) reconcebido ou pelo menos disputado. A metáfora da pipeline realiza uma forma de depuração desses intercursos "mais que humanos", incluindo a dimensão computacional. Em virtude disso, importa reconhecer que seus usos, à medida que produzem certo mundo dos dados, efetuam "consequências reais, intervenções, possibilidades criativas e responsabilidades de atuação interna dentro e como parte do mundo" (BARAD, 2007, p. 37). A correlação entre as lacunas e a metáfora da linha de 
produção enfatiza como "as práticas sempre têm o potencial de realizar algo diferente" (SCOTT; ORLIKOWSKI, 2014, p. 878). Por derivação, se lacunas coexistem, elas não poderiam dar lugar a ontologias mais vivas às lógicas mecanicistas? Em outras palavras, se o uso da metáfora apaga e simplifica a confusão desse processo animado e indisciplinado, ao fazê-lo, não precisaria apagar também os olhos que veem? Como Haraway (1995, p. 24), uma vez, perguntou: "com o sangue de quem foram feitos meus olhos?" Seria, por isso que, quando Stevens nos leva em uma incursão pelo Broad Institute e pelo Broad Sequencing Center - campos do seu trabalho etnográfico - há dois prédios diferentes situados em duas partes diferentes da cidade de Cambridge, Massachusetts?

O primeiro edifício é descrito como ornado com bastante vidro, apresentando uma imagem de transparência, enquanto o centro de sequenciamento permanece escondido em um parque industrial. A primeira construção representa uma história limpa e asseada do sequenciamento, um futuro livre de doenças, enquanto o segundo representa a confusão da realidade repleta de lacunas e, mais importante, de trabalhadores cuja história social e econômica é muito diferente daquela contada pelo Broad Institute. Mesmo as paredes de vidro transparente escondem segredos à vista. Considerando que o processo de sequenciamento em todos os níveis é altamente técnico e exige mão de obra qualificada e especializada, Stevens demonstra como esses trabalhadores são categorizados em produtores e consumidores. Os produtores são "indivíduos trabalhando para transformar amostras em dados" (STEVENS, 2013, p.73), e os consumidores são aqueles que "analisam esses dados e os transformam em conhecimento biológico" (STEVENS, 2013, p. 73). Os primeiros trabalham diretamente com amostras, técnicas, dispositivos tecnológicos, bancos de dados, software e hardware. O segundo grupo trabalha com o mesmo conjunto de entidades, mas recebe a autoridade para nomear o conhecimento, para dar nome à vida. Esse é apenas mais um exemplo do testemunho modesto em que certos "olhos" corporificam um discurso para proclamar uma verdade objetiva desencarnada, enquanto outros "olhos" não recebem o direito de ver.

Para o primeiro grupo, Stevens observa que é importante saber algo sobre biologia, mas "os doutores em biologia são poucos e distantes entre si. Muitos dos trabalhadores são jovens, frequentemente vindos diretamente de cursos de graduação em biologia. Há também um número desproporcional de não-brancos e imigrantes" (STEVENS, 2013, p. 91). De um lado, para um de nós, envolvido com as políticas curriculares norte-americanas, é de se perguntar, diante dessa divisão do trabalho científico, se não podemos ver esses jovens biólogos, trabalhadores racializados, como exemplos dos primeiros esforços para impulsionar a agenda educacional da política STEM ${ }^{9}$, que objetiva criar uma força de trabalho barata. Com efeito, Stevens observa (2013, p. 101), o objetivo do sequenciamento não é mais avaliado em torno de "quantos artigos são publicados ou quão promissora a pesquisa parece, mas com base em dólares por sequência [...] Progresso é entendido como o acúmulo de mais e mais dados de sequenciamento em um custo cada vez menor". O principal caminho através do qual as corporações multinacionais tecnocientíficas cortam custos não é pelo uso de técnicas melhores, mais rápidas e mais baratas, mas com a terceirização dos custos trabalhistas. Um jovem especialista em STEM declara para Stevens que é possível uma carreira rentável nas ciências, mas reclama que não é informado que o negócio de sequenciar "exige uma força de trabalho que não é treinada apenas em biologia e cujas habilidades podem ser transferidas para uma extensão das indústrias" (STEVENS, 2013, p. 101).

Essas novas formas de trabalho investem em políticas curriculares para novas formas de sociabilidade - mostrou Elizabeth Macedo (2015) ao se referir à Base Nacional Curricular Comum no Brasil -, mas não operam do mesmo modo em todos os espaços e tempos. Isso nos levou a fazer o seguinte questionamento: o que acontece quando, e não apenas hipoteticamente, esse trabalho terceirizado é enviado para outras áreas ou convoca sujeitos de outras partes do mundo à procura dessa mão de obra qualificada, mas mais barata? Por exemplo, ao analisarem o funcionamento do discurso do Programa Ciência Sem Fronteiras, no Brasil, Carina Merkle Lingnau e Pablo Navarro (2018) mostram como

\footnotetext{
${ }^{9} \mathrm{O}$ acrônimo em inglês para Science, Technology, Engineering, and Mathematics (em português, Ciências, Tecnologia, Engenharia e Matemática) dá nome a uma formulação curricular centrada na articulação de competências dessas áreas. Uma aproximação com as recentes políticas de centralização curricular no Brasil não é despropositada. Agentes como os mapeados por Macedo (2015) estão envolvidos tanto na formulação da Base Nacional Curricular Comum quanto na divulgação do STEM no Brasil, em iniciativas como as capitaneadas pelo grupo Positivo, pela Microsoft Brasil, com a tradução de material didático produzido pela empresa nos EUA, além da plataforma STEM Brasil lançada pela ONG Educando.
}

Educação em Revista|Belo Horizonte|v.36|e221497|2020 
seu acontecimento discursivo atualiza a ideia da educação para o trabalho tecnológico, e não a produção de conhecimento, como motores para o desenvolvimento da população brasileira. Não seria de se perguntar, assim, como o trabalho internacional racializado está implicado no sequenciamento da vida? Ericka Bullock (2017) indica como a institucionalização do processamento de dados entrincheira divisões raciais e abre caminho para a disseminação da branquitude. Os próprios conjuntos sociotécnicos de dados são também assombrados pelas relações sociopolíticas da racialização, nota Ezequiel Dixo-Roma'n (2017), haja vista que as formações ontológicas do "humano" não apenas garantem hegemonia através de narrativas, mas também são reiteradas por meio de tecnologias. A essa altura, estamos insistindo que é preciso cuidado para que os trabalhadores escondidos nos caminhos secundários de um parque industrial não sejam deglutidos quando a linha de produção dos dados dirigindo a vida é vista como transparente e rotineira. De certa forma, nós também salientamos um tipo de trabalho genético que entidades "não-humanas" realizam, os corpos de onde saem as amostras coletadas, parte considerável delas, extraídas de países ricos em biodiversidade para alimentar a fantasia da biblioteca do patrimônio genético da diversidade da vida ${ }^{10}$.

Entre as duas pontas, a produção e acumulação acelerada de dados do sequenciamento são práticas e relações tanto materiais quanto discursivas, orgânicas e inorgânicas em uma topografia irregular. Na notação de Rob Kitchin (2014), os dados são constituídos em uma multiplicidade de aparatos entrelaçados e variáveis, mutuamente constituídos, nos quais estão contidos ideologias, técnicas, interesses políticos, forças econômicas e práticas culturais. De tal modo, o próprio Dixo-Roma’n (2017) insiste que possibilitar condições para futuros alternativos exige da pesquisa em educação falar de, para e com a matéria fantasmagórica dos códigos ontológicos dos bancos de dados, pois tais intervenções forneceriam uma perspectiva diferente. Agenciamentos dos dados estão muito mais emaranhados nos fluxos materiais, semióticos e sociais da vida, de modo que esse engajamento articula (ou poderia articular) possibilidades políticas imprevistas. Nós ressoamos, assim, a sugestão de Wendy Chun (2011, p. 160), quando recomenda que, longe de reclamar sobre a falibilidade ou lamentar o controle das tecnologias preditivas, nós necessitamos "tomar suas previsões como um chamado para responsabilidade". Em nosso argumento, cultivar essa responsabilidade demanda redirecionar a relação ontoepistêmica entre ser e conhecer quando os dados tecnologicamente mediados entram na cena política - um movimento consistente com o que Astrida Neimanis (2012, p. 109-110) afirmou: "mesmo quando insistimos na responsabilidade, devemos também tomar decisões que evitem a certeza e os cursos de ação invitáveis. Essa é uma ética da incognoscibilidade".

Esse chamado ético tem um impacto no modo como pensamos a ação política da pesquisa em educação. Aqui, Stevens caracteriza ainda esses trabalhadores de outra maneira que nos é inspiradora para esboçar um caminho. Essa categorização é sobre fronteiras disciplinares.

Por nome e definição, a bioinformática é uma disciplina híbrida, construída a partir de biologia e informática. De fato, existem dois grupos bastante distintos de pessoas que habitam o campo. A primeira consiste em indivíduos com formação em ciências da vida que recorreram à computação para lidar com grandes quantidades de dados. A segunda consiste em indivíduos que foram treinados em ciência da computação, matemática ou engenharia [e] que se voltaram para a biologia para encontrar novos tipos de problemas e novas aplicações para suas habilidades de programação e construção de algoritmos (STEVENS, 2013, p. 51).

O que acontece com o campo da biologia quando é conduzido por algoritmos? O que acontece com uma disciplina, como a ciência da computação, quando entra em contato com entidades vivas? O sucesso do campo multidisciplinar da bioinformática vem transformando outras disciplinas, à medida que a matemática e a engenharia se tornam mais intricadas nas ciências biológicas. Resta-nos, por efeito, uma indagação: qual será o lugar das humanidades nesta transformação ou, em todo caso, a responsabilidade da pesquisa em educação nesse mundo "mais que humano"? Nós percebemos que há uma potente tarefa ética e política em manter aberta a lacuna entre a biologia, por um lado, e a matemática e a ciência da computação, por outro, a fim de participar desse jogo do que a vida poderá significar no

${ }^{10}$ Uma contribuição para este debate pode ser encontrada no trabalho de Manuela Carneiro da Cunha (1999). Educação em Revista|Belo Horizonte|v.36|e221497|2020 
presente e no futuro. O espaço aberto pela antropologia, tal como Stevens (2013) aborda, poderia ser ocupado por outras tradições de pesquisa que estão vivendo, mesmo que à revelia, essas formulações dos algoritmos, criando uma aliança tão dinâmica quanto imprevisível entre disciplinas. A recusa da ascese que cinde domínios de investigação é uma aposta no incognoscível para responder aos embaraços que "já nos conduzem ou nos convocam a desenvolver mais pudores em relação ao objeto estável dessa disciplina, a saber, o humano ou suas relações" (MARRAS, 2018, p. 251). Recusando, portanto, a distinção entre a objetividade distanciada da maquinaria tecnológica e, como contraparte, a subjetividade do "humano", essa aproximação da pesquisa em educação com os mundos dos dados tanto poderia desbancar a promessa de que faríamos um contato privilegiado com a realidade, quanto poderia nos convidar a nos sintonizarmos com as transformações ontológicas da percepção que os dados vêm realizando.

\section{ORDENANDO CONHECIMENTO = ORDENANDO A VIDA}

A forma pela qual as lacunas são abertas e preenchidas nos processos de sequenciamento da bioinformática depende de como os dados são ordenados. Por essa razão, Stevens empreende esforços consideráveis para descrever a história de como certas técnicas de ordenação surgiram e se desenvolveram na bioinformática. Esta história não deve ser vista como irreparável, em que os sistemas de ordenação eram inevitáveis. Para Stevens (2013, p. 138), "as bases de dados constroem ordenamentos de conhecimento científico: são poderosos esquemas de classificação que tornam algumas informações acessíveis e algumas relações óbvias, enquanto tornam outras ordenações e relacionamentos menos naturais e familiares". De pronto, os interessados na ordenação de dados foram apresentados a dois problemas. O primeiro era como disponibilizá-los ao maior número possível de usuários "garantindo que [os dados] pudessem ser compartilhados entre programas de computador" (STEVENS, 2013, p. 164). O resultado foi a conhecida criação de um padrão internacional, no qual computadores "poderiam se comunicar uns com os outros usando 'regras específicas para descrever objetos de dados e as relações entre eles" (STEVENS, 2013, p. 164). O segundo problema foi encontrar uma maneira de armazenar vários tipos de dados em uma forma que fosse adequada às necessidades dos biólogos que desejavam não apenas informações sobre sequências de DNA, "mas dados sobre outros aspectos do sequenciamento" (STEVENS, 2013, p. 164). O primeiro problema nivela os dados à necessidade de padrões internacionais universalmente aceitos (impostos?) para ordenação de dados, com regras estabelecidas a fim de enquadrar o processo. Os dados que não se encaixam nesses critérios são apagados. O segundo problema busca reinflar o processo de achatamento, acomodando tantos tipos diferentes de interesses de pesquisa quanto possível. Uma vez que a ordenação dos dados através de sistemas de computadores está em operação, a questão da ordenação torna-se uma questão de saber como a ordenação do conhecimento representará a ordenação da vida.

Bancos de dados não são conhecimentos biológicos, mas se tornam um caminho para o conhecimento e, no que diz respeito ao sequenciamento, são, certamente, um caminho ontológico. A maneira pela qual chegamos a conhecer e como chegamos a ser é cada vez mais uma questão de gerenciamento e ordenação de dados. Ser e saber surgem e se fundem a partir de algoritmos de tecnologia e ordenação computacional. Para Stevens (2013, p. 44), dados conformam "práticas de uso do computador: são as coisas que os computadores manipulam e operam. Dados não podem ser entendidos separadamente do computador e não têm significado fora de um contexto digital". Isso significa que aquilo que venha a se chamar de "humano" é um ser sempre mediado tecnologicamente, como Bernard Stiegler (1998) argumentou. Por efeito, não estamos afirmando que "seres humanos" possam ser reduzidos a imagens digitais, mas sim que o próprio "humano" está sendo transformado em e pelos dados digitalizados. A representação modelizada digitalmente do genoma não é o mesmo que a molécula de DNA em nossos corpos. Stevens (2013, p. 44) observa que "afirmar que a biologia está se tornando data, de certa forma, é dizer que ela está ligada a todos os tipos de práticas, estruturas e restrições associadas ao hardware e software". Esse hiato entre a vida e os dados digitalizados conduzindo a vida é, de longe, 
o mais importante para se lançar alguma preocupação. Uma exploração e uma reconstituição desse espaço lacunar podem abrir futuros alternativos.

No campo da pesquisa educacional, não é difícil ver como se é afetado por essa tendência em direção à digitalização e à ordenação de dados. Alunos e professores são agora definidos por dados gerados sobre eles e através deles, cujos efeitos subjetivos foram discutidos por Peter Taubman (2007). Esses dados compilados em nome e em substituição do aluno e do professor vão compor parte da sinfonia daquilo que Macedo (2017b) nomeou, inspirada em Wendy Brown (2015), de economização da política curricular. Para Benjamim Allen (2017), essa profusão de dados dirige, em grande parte, interesses de corporações e esforços políticos do neoliberalismo na educação básica. Se os dados não apontam para o sucesso educacional, o aluno deverá esperar encontrar apenas um estilo de vida precarizado no futuro; e, como consequência, se os dados indicarem que os estudantes não estão preparados adequadamente para o futuro, professores podem ser localizados, qualificados como ineficazes e, em alguns casos, sumariamente dispensados. Há - e como continua a nos assombrar, é motivo suficiente para insistir no neologismo numerentalização proposto por Clarice Traversini e Samuel Bello (2009), ao designarem a combinação entre práticas de governo e práticas de numerar, medir e contabilizar nas políticas educacionais - uma persistência anacrônica na certeza que a produção de dados poderia nos trazer; porém, não deixa de chamar atenção para como a associação entre dados e números é inevitavelmente contingente.

De fato, Daniel Rosenberg (2013) relata que a palavra "dado" etimologicamente significa algo que era usado para fins argumentativos, algo usado com objetivos fundacionais para realizar um jogo retórico. A questão é que as funções retórica e histórica dos dados foram apagadas e reduzidas a um significado mais preciso e limitado que os define como "informação em forma numérica" (ROSENBERG, 2013, p. 33). Como as ciências da vida se deslocaram das origens da palavra que Rosenberg menciona para o estatuto atual dos dados para mais do que uma base de suposições dadas para construir a vida? A viagem etimológica de Rosenberg $(2013,18)$ revela que o termo aparece em inglês no século XVII, e sua raiz latina significa "algo dado em um argumento, algo tomado como garantido". Esse significado implica dois efeitos. Ao apresentar um argumento a fim de persuadir alguém, significa que podemos usar quaisquer dados que consideremos necessários para apoiar uma reivindicação, mas não significa que, de maneira alguma, falamos a verdade. Quando apresentamos algo para apoiar um argumento, não implica falarmos com sinceridade, apenas apresentamos algo para suportar uma causa defendida. No entanto, seria preciso notar que, ao assumirmos que algo é garantido, produzimos uma reinvindicação de verdade. No mínimo, estamos oferecendo algo hipotético, cuja existência depende do efeito retórico implícito de "vamos assumir que" ou "você não concordaria comigo que". Tão logo algo seja assumido como dado ou se concorde sobre sua existência, estamos enredados nos pressupostos de fabricação do mundo.

Theodore Porter (1995) conta, nesse sentido, uma das histórias possíveis das razões pelas quais os números ou a quantificação se tornaram tão importantes para nós. As pessoas, hoje, em muitas partes do mundo, confiam nos números mais do que nas "simples" histórias que os indivíduos contam, como se os números não contassem histórias. Os números passaram a dominar vários campos do conhecimento, como a economia, e, segundo Stevens aponta, a biologia, porque ofereceriam uma ilusão de estabilidade e certeza. Certamente, essa fantasia de segurança oferece a biólogos, economistas, engenheiros, matemáticos, empresários e líderes políticos uma paz de espírito ou um alicerce retórico em qualquer debate, ajuizando que seus argumentos são sólidos e racionais o suficiente para justificarem o que se almeja realizar. Os números, especialmente na forma de bancos de dados, permitiriam que figuras políticas, provedoras de confiança, apresentassem "evidências" da solidez de decisões e da veracidade das políticas. Nós nos juntamos a Elizabeth St. Pierre (2013, p. 223) quando esta afirma que "está interessada na ocasião do aparecimento dos dados; isto é, em quando, onde, por que, como e por quem os dados são convidados a fazer algum trabalho". A emergência de uma vasta e volumosa ordenação de informações marca o início da transformação da biologia em uma ciência computacional e matemática. Os números marcam o começo de sua estabilização, tal como se buscaram estabilizar a física e a astronomia a fim de que pudessem fazer afirmações cada vez mais gerais e abrangentes sobre o alcance 
e a relevância de seu campo. Mesmo que assumamos que são formulações geopoliticamente localizadas, sua conectividade transnacional não circunscreve seus efeitos.

Alain Desrosieres (2009, p. 312) levanta uma questão semelhante quando pergunta "qual é o propósito do próprio ato de quantificar e a quem serve?” Como indicado por St. Pierre (2013), Desrosieres também levanta questões de poder: a que estrutura e a quem os dados são leais? Desde o início do desenvolvimento de estatísticas e dados numéricos, os estados nacionais entenderam a importância dessas ferramentas para a construção de significados - e isso foi o que Foucault (2008) demonstrou com clareza. A palavra estatística em si refere-se a funcionários do estado que coletavam informações para controlar e governar a população. Desrosieres (2009, p. 318) salienta que "a unificação política e a unificação estatística andam de mãos dadas". Como o autor sugere, "a quantificação serve para fornecer ferramentas para comparações [...] coordená-las padronizando-as, e controlando e estimulando os jogadores, classificando seus desempenhos em escalas normativas" (DESROSIERES, 2009, p. 312). Quais áreas são mais propensas ao crime? Onde deve ser localizada a força policial? Quais unidades militares são mais eficazes e estão prontas para o combate? Quais são as taxas de suicídio mais altas e por quê? Quais professores são mais eficientes no desempenho de suas funções para organizar escolas e preparar os alunos para o mercado de trabalho? Quaisquer que sejam as respostas, elas podem ser quantificadas para fornecer uma descrição simplificada. Os bancos de dados servem para avaliar, julgar, condenar, implantar, honrar, desgraçar, monitorar, regular e promover sua população. Eles nos lembram que vivemos em uma sociedade, como se fosse um organograma desenhado através de gráficos, tabelas, relatórios e marcas de todos os tipos.

No entanto, dados, Rosenberg (2013, p. 18) sugere, são diferentes de fatos e evidências, já que "fatos são ontológicos, evidências são epistemológicas, dados são retóricos". A diferença entre fato, evidência ou verdade reside na seguinte assertiva: "quando um fato é provado falso, deixa de ser um fato. Dados falsos, no entanto, são dados" (ROSENBERG, 2013, 18). Para bem dizer, fato, verdade, evidência e dados tornaram-se progressivamente interligados. Como Rosenberg (2013, p. 22) acrescenta, o estado atual em que nos encontramos é o de estarmos "nadando em dados", e dispara ainda que "o futuro será os dados". Kitchin (2014) chega mesmo a descrever o atual estado de coisas como um dilúvio de dados. Contudo, há uma parte importante que, em nossa perspectiva, está ausente. Embora fatos, evidência e verdade tenham se tornado mais emaranhados com dados, isso não significa que a mistura seja confortável ou, de forma suspeitável ainda, pura. Apesar de sua conexão mais próxima com reivindicações da verdade, Rosenberg (2013, p. 37) observa que "os dados não têm verdade. Ainda hoje, quando falamos de dados, não fazemos suposições sobre a veracidade". Pode ser que os dados que coletamos e transmitimos não tenham relação com a verdade ou realidade, além daquela que eles próprios ajudam a construir. Geoffrey Bowker (2013, p. 170-171) declara, assim, "se você não está em um banco de dados, você não existe" e "estamos gerenciando o planeta e uns aos outros usando dados", mas afirma que, por isso mesmo, "precisamos é de uma abordagem [...] para analisar as formas que os dados tomam [...] que nos permita vislumbrar novos futuros possíveis". Tudo pode estar se tornando dados ordenados em sistemas tecnológicos; podemos estar nadando em um oceano infinito de dados cheios de ameaçadores tubarões; nossas subjetividades podem ser constituídas através dessa ordenação, mas nada disso é a mesma coisa que fato, verdade e, muito menos, realidade. Os ambientes, as estruturas, as lógicas e os fundamentos para pensar, agir e mesmo acreditar não estão prontos, não são transparentes; precisam ser inventados.

Há um trabalho de composição a ser feito. Como Stevens nos mostra, os dados precisam ser limpos e manipulados para se adequarem a certo modo de pensar, ordenados para certos sistemas de armazenamento, certas visões de mundo ou certos modelos de vida gerados por computador. Se é aqui que a bioinformática floresce, nosso lugar não está em drenar esses grandes volumes de dados como se não tivéssemos outro papel. Ao invés disso, em nome de nossas existências, devemos contestar quaisquer ordenações de dados que dirijam a construção de quem somos e quais delas nosso futuro poderá comportar. É de se notar como, na tradução para o português, o verbo to drive, se usado em sentido figurado em inglês, pode significar "impulsionar", sem que, portanto, o movimento de dirigir tenha direção previsível, permitindo realçar os dados mais como propulsões, como catapultas. A fim de desafiar os limites de qualquer ordenamento do conhecimento e da existência, nós precisamos entrar nos mundos 
dos dados (ou assumir que não podemos mais sair deles), entender seu funcionamento e impulsionar maneiras outras de saber e ser dentro eles. Isso significa que os mundos construídos pela bioinformática não precisam ser criticados para, de saída, já serem deixados de lado. Podemos nos envolver com eles? Podemos construir conjuntos próprios de dados para oferecer caminhos outros? Esses conjuntos de dados podem ser matemáticos e quantificáveis, mas não precisam ser limitados a esse ponto. Se dados estão por toda parte e estamos nadando dentro disso, a vida constituída através deles consiste em muito mais do que formas numéricas e quantificadas. A história da onipresença dos dados não é o fim da história.

Nesse cenário, reconhecemos, entretanto, que é difícil imaginar contestações. Todavia, gostaríamos de sugerir que, com Jacques Derrida (2001), é possível argumentar nesse sentido. Derrida (2001, P. 12-13) nos diz que

o sentido de 'arquivo', seu único sentido, vem do arkheion grego: inicialmente uma casa, um domicílio, um endereço, a residência dos magistrados superiores, os arcontes que comandavam. [...] Levada em conta sua autoridade publicamente reconhecida, era em seu lar, nesse lugar que era a casa (casa particular, casa de família ou casa funcional) que se depositavam então os documentos oficiais. Os arcontes foram os seus primeiros guardiões. [...] Tinham o poder de interpretar os arquivos (DERRIDA, 2001, p, 12-13).

Com essa lição sobre as origens gregas do termo arquivo, vemos as conexões que estamos apontando entre controle e estatística. O titular desses documentos tem o poder de conferir significado sobre o que os dados significam e declarar quem existe e quem não é uma entidade. Derrida (2001, p. 14, grifos nossos) comenta que o poder arcôntico do arquivo "que concentra também as funções de unificação, identificação, classificação, caminh[a] junto com o que chamaremos o poder de consignação [...] o ato de consignar reunindo os signos". Não é isso que a estatística realiza? Esse grande volume de dados tecnologicamente mediados não funciona como compilado para instituições governamentais, econômicas e educacionais a fim de garantir que decisões possam ser tomadas, políticas criadas, diplomas conferidos e vidas construídas? Derrida (2001, p. 14) declara que "não pode haver poder político sem controle do arquivo, se não da memória. A democratização efetiva se mede sempre através deste critério essencial: a participação e o acesso ao arquivo, à sua constituição e à sua interpretação". Seria por isso que celebrações de poder estariam vinculadas a uma biblioteca, tais como Alexandria na Roma Antiga, os mosteiros da Europa Medieval, as novas universidades napoleônicas da França e a Biblioteca do Congresso Nacional dos Estados Unidos? Ou, agora, ao que parece, ao acervo genético tecnologicamente disponível dos grandes laboratórios e corporações científicas? Esses corpos arquivísticos foram formados para controlar a memória e determinar parâmetros de participação e acesso à memória?

Esse impulso para controlar a participação e o acesso ao arquivo é uma questão do passado - o que se disse, o que se fez, quem foi quem - e uma questão de futuro - como alguém será lembrado, se for o caso, e como será reconstruído por outros, se for possível. $O$ arquivo esforça-se, simultaneamente, para manter o passado vivo e assegurar a possibilidade do futuro. Ao mesmo tempo, Derrida destaca que o arquivo procura eliminar o passado e o futuro. O arquivo preserva algo do passado, mas, assim que algo é preservado, o passado é eliminado e reduzido à unidade que foi preservada. $\mathrm{O}$ arquivo destrói o passado pelo ato de preservar ou abrigá-lo. O que resta é o que é lembrado, e a forma como as instituições educacionais e políticas são estruturadas determina como o que resta será lembrado no futuro. O ato de arquivar baseia-se em um ato de violência (DERRIDA, 2001). Aquilo que é preservado e abrigado com segurança para um futuro desconhecido destrói o passado e, em todos os casos, elimina a maioria das pessoas e seres sencientes "não-humanos" da existência. Esses seres morreram e foram, sobretudo, apagados quando o arquivo preservou apenas um pedaço deles ou mesmo nada. Na declaração incisiva de Derrida apud Naas (2015, p. 135), "o arquivo [...] é um movimento irresistível não apenas para manter traços, mas para dominá-los, interpretá-los”. O impulso para preservar e dominar sonha em controlar o futuro.

Os dados digitalizados marcam quem somos para nós mesmos, para agências governamentais, instituições educacionais; mas também eliminam (ou buscam) quem somos e quem podemos ser. Os dados transformam-nos em documentos arquivados, na forma de quanto ganhamos, 
de que receitas nós dispomos, que produtos compramos, que sequências incorporamos e como consumimos. Na motivação para governos e corporações coletarem dados, há um impulso para dominar indivíduos, para ditar quem deve viver e quem deve morrer, quem terá futuro e quem não terá sequer um passado. A ordenação dos dados é um arquivo que constrói com violência quem as pessoas e entidades "não-humanas" são e quais objetos são reconhecíveis. Porém, Stevens contestaria a afirmação de que não haverá futuro aberto se formos engolidos pelos bancos de dados, ao demonstrar como a bioinformática tomou sequências de entidades "humanas" e "não-humanas", convertendo-as em vida digitalizada. Sua conclusão é de que somos testemunhas do eclipse de uma nova figura: o Homo Statisticus.

A vida útil dos dados tornou-se tão bem-sucedida que "os rastros digitais de sequências vão parecer cada vez mais substitutos para as próprias amostras biológicas" (STEVENS, 2013, p. 207). A própria digitalização oferece uma solução para a questão do custo. "Se amostras ou espécimes ou materiais biológicos puderem ser digitalizados de forma rápida e barata, fica ainda mais fácil substituir o material pelo virtual" (STEVENS, 2013, p. 207). O virtual pode ser usado repetidamente em diferentes ordens e configurações, sem ter que passar pelo processo de sequenciamento novamente. O custo é reduzido, e o escopo e talvez a existência da indústria de bioinformática podem ser apagados. Quem precisa de qualquer empresa de bioinformática se todas as sequências necessárias já estiverem no banco de dados do próprio computador ou em algum lugar em um banco de dados onde o computador possa recuperá-lo? Esse potencial da pesquisa implica que "a própria bioinformática poderá ser apagada: o biológico se tornará a informática" (STEVENS, 2013, p. 207). O "humano" aparecerá como um corpo estatístico digital, no qual quaisquer desvios seriam mais um problema solucionável através da correta sequência gerada por computador, pronta para ser transplantada para o corpo, apagando, por efeito, a sequência que provoca o deslocamento. A sequência digitalizada arquivada em uma biblioteca virtual, que elide o passado, é um dispositivo para revistar a história, para traçar uma história outra do corpo do "humano", menos centrada na sua autonomia excepcional. "O arquivo trabalha sempre contra si mesmo" nota Derrida (2001, p. 24). O Homo Statisticus é uma entidade dirigida por dados que ganha vida apenas porque é uma entidade "mais que humana", que se tornou possível graças a dispositivos tecnológicos. Nesse mergulho, o processo de sequenciamento oferece uma chance de reimaginar um envolvimento perceptivo com o mundo dos dados, inspirado pelas lacunas abertas e elipses incognoscíveis do próprio vir à tona, mutualmente engajado entre corpo e tecnologia do Homo Statisticus.

\section{DIRIGINDO A VIDA?}

O mais recente trabalho de Mark Hansen (2015) demonstra que o fenômeno do Homo Statisticus e da acumulação e produção de dados dirigindo a vida não é um desafio que biólogos, matemáticos e cientistas da computação enfrentam sozinhos. É uma questão que altera fundamentalmente o próprio laço social. No século XXI, a mídia, para Hansen (2015, p. 51), é diferente daquela vivida no nosso século anterior.

Nosso novo paradigma de humano co-funcionando com técnicas e máquinas é necessário para registrar e interpretar os dados sensoriais que constituem a experiência, e tais dados englobam eventos que ambientalizam a relação com um centro experiencial [...] assim como eventos que envolvem diretamente a incorporação de tal centro (por exemplo, dados biométricos que não podem ser acessados diretamente por meio da percepção e da consciência) (Hansen, 2015, p. $51)$.

No século XX, formas de mídia e tecnologia amplificaram nossas percepções e estenderam nosso alcance sobre o ambiente. Por exemplo, um microscópio ampliou a nossa visão, e um carro distendeu as capacidades "humanas" para viajar longas distâncias em um tempo razoável, alterando nossas experiências. Hansen está sugerindo que as tecnologias do século XXI estão moldando a realidade antes de chegarem ao campo da percepção. Hansen (2015, p. 52) sustenta que 
a mídia do século XXI ultrapassa os limites temporais da percepção sensorial [...]: enquanto a consciência perceptual só pode experimentar sensibilidade micro-sensorial [...], os sensores técnicos agora onipresentes em nossos ambientes vividos são capazes de captar eventos experienciais diretamente no nível microtemporal de sua operacionalidade e independentemente da mediação da consciência. [São capazes de] transmiti-los para frente em consciências futuras ou 'prontas' de modos que podem influenciar a agência futura da consciência no mundo.

As interações "humanas" imaginadas como "naturais" consistiram, quase sempre, em aceitar que habilidades sensoriais e motoras alimentam nosso corpo e mente à medida que criam experiências perceptivas. Porém, em nossa hipótese - e frisamos o caráter hipotético, porque estamos começando a nos enveredar por esse caminho -, os meios tecnológicos geradores de dados independentes estão moldando nossas experiências sensoriais antes mesmo de chegarem ao nível perceptivo consciente, conformando o sentido de agência. Não é como se dados tivessem intencionalidade, mas sim que os seus efeitos, embora múltiplos e dispersos, dirigindo a vida, pudessem ser sentidos em toda parte. Se a mídia do século XIX ajudou a formar nossas experiências como "humanos", em nossos tempos, as percepções são alteradas antes que saibamos que as temos, por meio de dados tecnológicos gerados por entidades de sensores de semáforo, algoritmos da Amazon ou do Facebook, resultados de testes educacionais ou sequenciamento de imagens digitais. Em outras palavras, se, como afirmaram Marshall McLuhan e Quentin Fiore (1967), em título de um clássico dos estudos da comunicação, "o meio é a mensagem", a vida não é apenas dinamicamente dirigida pelos bancos de dados, mas quaisquer acumulação e produção de dados são a própria mediação tecnológica da vida, através da qual as suas superfícies sensíveis não são produzidas como reflexos, mas como modos de perceber imersos nesse mundo dos dados.

Em resumo, a natureza mutável dos dados computadorizados não é sobre os "humanos" perdendo o controle, mas como dados estão moldando o ambiente em que vivemos. Hansen (2015, p. 53) conclui, deste modo, que, "por este motivo, dados contemporâneos de sensibilidade podem ser definidos como data porque que não podem ser vividos diretamente pela consciência". Novas tecnologias geradoras de dados estão agindo no sentido de conformarem o próprio meio em que "humanos" imaginam atuar conscientemente e em suas relações com ele. Nosso interesse pela composição molecular biotecnologizada da vida não é apenas uma questão fisiológica, é uma questão histórica e política que leva à pesquisa em educação. O que acontece com nossas experiências e reações conscientes - marca, por exemplo, dos discursos mobilizadores de ensinar e aprender (TAUBMAN, 2007), do construtivismo pedagógico (SILVA, 1998) às competências (BIESTA, 2014) - quando nosso viver no mundo é fundamentalmente moldado e alterado por dados gerados em computadores e à revelia de nossa vontade? $\mathrm{Na}$ pesquisa em educação, não é de se estranhar que essas técnicas ganhem ressonância nas políticas curriculares recentes pela confiança na padronização, no potencial para vastos conjuntos de dados e na criação de plataformas virtuais de dados sobre a vida nas escolas, de professores e alunos. Escolas e, em especial, o trabalho de professores são alvos especialmente sensíveis de racionalidades políticas marcadas por desejos utópicos maquinados por essas mudanças tecnológicas e fluxos capitalistas cada vez mais explícitos. Todavia, não é que as relações educacionais envolvam, agora, tecnologias e dados; tecnologias e dados já eram, anteriormente, relacionais.

As indicações que viemos sobrepondo podem finalmente ser agrupadas. Essas reconfigurações derrubam noções convencionais de ensino e de aprendizagem, como uma modalidade perceptiva centrada em um agente "humano" individual em nome de uma sensibilidade ambiental espraiada. No coração da pesquisa em educação está uma cartografia desse contato sensorial expandido que, ao caracterizar a sensibilidade mundana digital, em virtude de estarmos mergulhados nesse oceano de dados, recoloca, como registra Elizabeth De Freitas (2017), o "humano" como uma figura inseparável e dependente do ambiente mais amplo. O mundo dos dados incide sobre a contingência dessa figura. A razão pela qual nós percebemos é por estarmos contidos e por virmos à tona dentro e na interface, com ambientes tecnologicamente mediados. O mundo dos dados serve como condição de possibilidade para o Homo statisticus porque a relação é tão necessária quanto irredutível para sua existência. Antes do nascimento e até depois da morte, o corpo torna-se algo "mais que humano". A figura do Homo Statisticus está além de uma entidade fornecedora de dados. Não é a mera incorporação de um ethos biotecnológico e informatizado; é o corpo sensível modificado e produzido por dados gerados tecnologicamente que 
fazem mais do que simplesmente informar médicos, políticos e até mesmo professores. Esse corpo está sendo feito e é efeito através de "se ramificar em territórios além de sua própria auto-manutenção" (COLEBROOK, 2014, p. 26). Dados deslocam os corpos de uma existência a priori para colocá-los dentro do que chamamos vida (como que situados em uma história que liga ambiente, percepção e tecnologia) para além ou aquém de selfs desejosos de uma propriedade excepcional. Ao perturbar a projeção do indivíduo autonomista como metonímia essencial para direção da vida, dados expõem os limites da ontologia política moderna. Como que em uma virada, são as fantasias dessa ontologia que se tornam subitamente assustadoras ou ainda simultaneamente perturbadas pelos mundos dos dados.

Toda essa geração de dados é parte de um cenário distópico do qual, talvez, não estejamos muito longe. A proposição política de Hansen (2015, p. 74), para viver nessa paisagem, é a de adotar o que ele chama de "o princípio da neutralidade dos dados", no qual "o potencial oferecido pela mídia do século XXI para coleta, análise e previsão de dados devem ser mantidas, fundamentalmente comuns a todos, publicamente acessíveis e abertas a múltiplos usos". Com relação ao domínio da bioinformática, o software de armazenamento, construído para abrigar as crescentes sequências digitalizadas de DNA, está aberto a qualquer biólogo interessado. No entanto, talvez devêssemos ir mais além do que somente acessar plataformas digitais. Seria preciso ter acesso a esses bancos de dados e à maneira como eles estão sendo utilizados. Mesmo que essa indicação possa não ser bem aceita por quem deseja patentear e controlar o fluxo do sequenciamento, a luta pelas informações geradas é um campo de batalha em que se determinam quais interesses regulam o acesso e o significado dos arquivos de dados. Em resumo, a forma como dados são gerados e o que podem significar e materializar abre um flanco para resistir à confortável denúncia do misterioso poder de predição e modelagem do sequenciamento, e demanda examinar os modos pelos quais corpos, ambientes e tecnologias se misturam de novas maneiras. Porém, mais ainda, e de forma especial, dados ajudam a interrogar onde os fundamentos de uma democracia viva podem residir. Longe de querermos ser programáticos, nós buscamos driblar a avaliação de fatos ou de julgamentos de práticas da bioinformática para sugerir que esse oceano de dados possa ser visto como intrinsecamente envolto num campo público, aberto e disputado, posto que nenhum trabalho político responsável pode mais ser feito dentro e por mundos que poderíamos tomar por objetiváveis.

Não é sem razão que a pesquisa educacional está na berlinda. À medida que a formulação de políticas é mergulhada no dilúvio de dados, qualquer assunção teórica sobre como as próprias noções de "social" e "humano", por exemplo, são transformadas pela mediação tecnológica é dispensada. No entanto, como esperamos ter defendido, não podemos dormir tranquilos com uma crítica moralizante dessas políticas. Esse velho "truque de deus" (HARAWAY, 1995, p. 15) resiste às tentativas de imaginar uma abordagem que funcione de dentro dos problemas em que residimos. Sustentar uma perspectiva crítica dessas reconfigurações é pensar mais criativamente sobre outros caminhos a serem inventados. "Pensar, nós devemos pensar", insiste Haraway (2016, p. 36) - isso significa adicionar camadas de histórias ao invés de conformar categorias prontas. $\mathrm{O}$ trabalho de fazer flertar a pesquisa em educação com os estudos da ciência e da tecnologia talvez seja um modo de torná-la mais próxima ao SF, em referência à própria Haraway (2016), próxima à "ficção científica, fabulação especulativa, feminismo especulativo, fatos científicos" - um trabalho de criação que inclui palavras e imagens, uma prática e um processo para fazer justiça à alteridade. Não podemos nos contentar com apontar o dedo para a incompletude de nossos modos de produzir pesquisa ou para o desejo desmesurado de controle mobilizado na política educacional. Qualquer alternativa de pensamento depende de absorvermos o ambiente tecnológico e computacional de nossos dados atuais, uma vez que estes estão compondo a cena política, de forma mais esplêndida e especulativa. Na sugestão de Luciana Parisi (2017), é “a reprogramação do pensamento através e com as máquinas [...], uma articulação paralela de filosofias das máquinas que contribuem para a reinvenção de mundos, verdades e fatos que existem e podem mudar”. Reimaginar a experiência dos dados, no emaranhado de meios animados, envolve intensificar formas de estarmos juntos, de ecoarmos as lacunas, de reverberarmos o incognoscível à percepção - tudo aquilo não está servindo ao conjunto instrumental de lógicas de controle da vida. 


\section{REFERÊNCIAS}

ALLEN, B. Exploring the Role of Ideology in Interdisciplinary Science Education Policy.

Educational Studies, v. 53, n. 6, p. 642-653, 2017.

BACHELARD, G. A formação do espírito científico. São Paulo: Civilização Brasileira, 2001.

BARAD, K. Meeting the Universe Halfway. Durham: Duke University Press, 2007.

BERNSTEIN, B. A estruturação do discurso pedagógico. Classe, códigos e controle. Petropólis: Vozes, 1996.

BIESTA, G. Para além da aprendizagem. Belo Horizonte: Autêntica, 2014.

BOWKER, G. Data Flakes: An Afterward to 'Raw Data' is an Oxymoron. In: GITELMAN, L. (ed).

"Raw Data" is an Oxymoron. Cambridge, MA: MIT Press, 2013. p. 165-171.

BRITZMAN, D. The very thought of education. Albany: State University of New York Press, 2009.

BROWN, W. Undoing the demos. Nova York: Zone Books, 2015.

BULLOCK, E. Only STEM Can Save Us? Examining Race, Place, and STEM Education as Property. Educational Studies, v. 53, n. 6, p. 628-641, 2017.

BUTLER, J. Fundamentos contingentes: o feminismo e a questão do "pós-modernismo". Cadernos Pagu, v. 11, p. 11-42, 1998.

CHEAH, P. Inhuman Conditions. Cambrigde: Havard Univerisy Press, 2006.

CHUN, W. Crisis, crisis, crisis, or sovereignty and networks. Theory, Culture \& Society, v. 28, n. 1, p. 91-112, 2011.

COLEBROOK, C. Death of PostHuman. Ann Arbor: Open Humanities Press, 2014.

CUNHA, M. C. Populações tradicionais e a Convenção da Diversidade Biológica. Estudos Avançados, v. 13, n. 36, p. 147-163, 1999.

DE FREITAS, E. Calculating matter and recombinant subjects: The infinitesimal and the fractal fold. Cultural Studies - Critical Methodologies, v. 16, n. 5, p. 462-470, 2016.

DE FREITAS, E. The temporal fabric of research methods: Posthuman social science and the digital data deluge. Research in Education, v. 98, n. 1, p. 27-43, 2017.

DERRIDA, J. Mal de arquivo. Rio de Janeiro: Relume Dumará, 2001.

DESROSIÈRES, A. How to be Real and Conventional: A Discussion of the Quality Criteria of Official Statistics. Minerva, v 47, p. 307-322, 2009.

DIXON-ROMA ${ }^{\prime}$ N, E. Toward a hauntology on data: On the sociopolitical forces of data assemblages. Research in Education, 2017, v. 98, n. 1, p. 44-58, 2017.

FOUCAULT, M. Segurança, território e população. São Paulo: Martins Fontes, 2008. 
HANSEN, M. Feedforward: On the Future of twenty-first-century Media. Chicago: University Of Chicago Press, 2015.

HARAWAY, D. Staying with the trouble. Durham, NC: Duke University Press, 2016.

HARAWAY, D. Manifesto ciborgue: Ciência, tecnologia e feminismo-socialista no final do século XX. In: TADEU, T. (org). Antropologia do ciborgue. Belo Horizonte: Autêntica, 2009. p.33-118.

HARAWAY, D. When species meet. Minneapolis: University of Minnesota Press, 2008.

HARAWAY, D. Saberes localizados: a questão da ciência para o feminismo e o privilégio da perspectiva parcial. Cadernos Pagu, v. 5, p. 7-41, 1995.

HARAWAY, D. The Promises of Monsters: A Regenerative Politics for Inappropriate/dOthers. In: GROSSBERG, L; NELSON, C; TREICHLER, P. (eds). Cultural Studies. Nova York: Routledge, 1993. p. 295-336.

JENSEN, C. B. New ontologies? Reflections on some recent "turns" in STS, anthropology and philosophy. Social Anthropology, v. 25, n. 4, p. 525-545, 2017.

KITCHIN, R. The Data Revolution. Thousand Oaks: Sage, 2014.

KNORR-CETINA, K. Epistemic Cultures. Cambridge, MA: Harvard University Press, 1999.

LARROSA, J. Tecnologias do Eu e Educação. In: SILVA, T. T. (org). O sujeito da educação. Petrópolis: Vozes, 2010. p. 35-86.

LATOUR, B. Jamais fomos modernos. São Paulo: Ed. 34, 2013.

LATOUR, B; WOOLGAR, S. Laboratory life. Londres: Sage Publications, 1979.

LATTER, P. Top Ten+ List: (Re)Thinking Ontology in (Post)Qualitative Research. Cultural Studies $\leftrightarrow$ Critical Methodologies, p. 125-131, v. 16, n.2, 2016.

MACEDO, E. Base Nacional Curricular Comum: Novas Formas de Sociabilidade Produzindo Sentidos Para Educação. Revista e-Curriculum, v. 12, n. 3, p.1530 - 1555, 2014.

MACEDO, E. Mas a escola não tem que ensinar?: Conhecimento, reconhecimento e alteridade na teoria do currículo. Currículo sem Fronteiras, v. 17, n. 3, p. 539-554, 2017.

MACEDO, E. As demandas conservadoras do movimento escola sem partido e a base nacional curricular comum. Educação \& Sociedade, v. 38, n. 139, p.507-524, abr.-jun., 2017

MALABOU, C. Plasticity at the Dusk of Writing. Nova York: Columbia University Press, 2005.

MARRAS, S. Por uma antropologia do entre: reflexões sobre um novo e urgente descentramento do humano. Revista do Instituto de Estudos Brasileiros, n. 69, p. 250-266, 2018.

MCLUHAN, M; FIORE, Q. The medium is the message. Londres: Peguin Books, 1967. 
MERKLE LINGNAU, C.; NAVARRO, P. "Ciência Sem Fronteiras" como acontecimento discursivo e dispositivo de poder/saber. Educação em Revista, v. 34, e181284, 2018.

MEYERS, N. Rendering Life Molecular. Durham: Duke University Press, 2015.

NAAS, M. The End Of The World And Other Teachable Moments. Nova York: Fordham University Press, 2015.

NEIMANIS, A. Hydrofeminism: Or, on becoming a body of water. In: GUNKEL. H; NIGIANNI, C.; SÖDERBÄCK, F (eds). Undutiful Daughters. New York: Palgrave Macmillan, 2012, p. 96-115.

PARISI, L. Reprogramming Decisionism. e-flux, v. 85, p. 1-12, out. 2017.

PICKERING, A. The Mangle of Practice. Chicago: University of Chicago Press, 1995.

PORTER, T. Trust in Numbers: The Pursuit of Objectivity in Science and Public Life. Princeton, NJ: Princeton University Press, 1995.

PROSDOCIMI, F. Racionalizando a utilização do algoritmo PHRED para a análise de seqüências de DNA: Questionando dogmas genômicos. Tese (Doutorado em Bioinformática) Universidade Federal de Minas Gerais, Belo Horizonte, 2006.

RHEINBERGER, H. Toward a History of Epistemic Things. Stanford, CA: Stanford University Press, 1997.

ROSENBERG, D. Data before the Fact. In: GITELMAN, L. (ed). "Raw Data" is an Oxymoron. Cambridge: MIT Press, 2013. p 15-40.

SILVA, T. T. (org). Liberdades reguladas: a pedagogia construtivista e outras formas de governo do eu. Petrópolis: Vozes, 1998.

SCOTT, S; ORLIKOWSKI, W. Entanglements in Practice: Performing Anonymity Through Social Media. MIS Quarterly, v. 38, n. 3, p. 873-893, 2014.

SPIVAK, G. A critique of postcolonial reason. Cambridge: Harvard University Press, 1999.

ST. PIERRE, E. The Appearance of Data. Cultural Studies $₫=>$ Critical Methodologies, v. 13, n. 4, p. 223-227, 2013.

STEVENS, H. Life out of Sequence: A Data Driven History of Bioinformatics. Chicago: University of Chicago Press, 2013.

STIEGLER, B. Technics and Time, 1. Stanford, CA: Stanford University Press, 1998.

TAUBMAN, P. Teaching by numbers. Nova York: Routledge: 2007.

TRAVERSINI, C; BELLO, S. O numerável, mensurável e auditável: estatística como tecnologia para governar. Educação e Realidade, v. 34, p. 135-152, 2009.

VERRAN, H. A Postcolonial Moment in Science Studies: Alternative Firing Regimes of Environmental Scientists and Aboriginal Land owners. Social Studies of Science, v. 32, n. 5-6, p. 729-76, 2002. 
WARREN, R. Purpose Driven Life. Nova York: Zondervan, 2002.

WEBER, S. Mass Mediaurus. Stanford, CA: Stanford University Press, 1996.

WORTMANN, M. L. C.; VEIGA-NETO, A. Estudos Culturais de Ciência e Educação. Belo Horizonte: Autêntica, 2001.

Submetido: $20 / 03 / 2019$

Aprovado: $04 / 08 / 2020$ 